\title{
The Legality of The Provision of Remission To Military Prisoners In Accordance With The Equality Before The Law Principle
}

\author{
Endah Wulandari ${ }^{1}$, Hedwig Adianto Mau ${ }^{2}$ \\ \{endahwulandari101010@gmail.com ${ }^{1}$ \} \\ Doctor of Law, Universitas Jayabaya, Jakarta, Indonesia ${ }^{12}$
}

\begin{abstract}
The Provision of Remissions to Napimil (Military Prisoner) at Lemasmil (Military Penitentiary Institution) is an effort to integrate social reintegration so that soldiers who have the TNI identity are guided by the Soldier's Code of Ethics and / or Officer Code of Ethics, are aware of their mistakes, improve themselves, and do not repeat criminal acts so that they can be accepted and returned to its unit in accordance with the provisions of laws and regulations. Thus, granting remissions to Napimil at Lemasmil is an effort to social reintegration of Napimil, so it needs to be regulated with a clear and straight regulations, in relation to the authority of the TNI Commander in granting Remission requests. The granting of authority to the TNI Commander can only be done if the Military Correctional Law has been issued. Given the importance of structuring the military correctional system, including the provision of remissions for Napimil, it is necessary to support the various competent parties to encourage the Military Correctional Bill to become a priority so that it can be immediately passed along with its derivative regulations.
\end{abstract}

Keywords: Napimil; social reintegration; remission; law and regulation

\section{Introduction}

In the administration of military correctional facilities, one of the rights of Napimil is to obtain Remission, the same as the rights of civilian / general prisoners as stated in Article 14 letter (i) of Corrections Law Number 12 of 1995 "prisoners are entitled to a reduced sentence (remission)." However, in reality the fulfillment of the right to Remission for Napimil has not been implemented properly due to administrative/procedural constraints such Remission for Napimil not being granted by the Minister of Law and Human Rights. In practice, the implementation of Remission for Napimil submitted to the Ministry of Law and Human Rights by the Military Penitentiary Center (Puslemasmil) often experiences obstacles because the Ministry of Law and Human Rights thinks that granting Remissions to Napimil is not under their authority, but the authority of the TNI Commander. In fact, up until now there has been no legal basis to issue a TNI Commander's Regulation regarding Remission for Napimil.

Granting Remissions for Napimil is part of the Military Correctional duties in Lemasmil. The Military Correctional System was held to foster Napimil with integrated social guidance and reintegration aimed at fostering Napimil to become soldiers who have the TNI's identity who are guided by the Soldiers 'Code of Ethics and/or Officers' Code of Ethics, realizing their mistakes, correcting themselves, and not repeating the previous crime, so They can be accepted backto their unit in accordance with the provisions of laws and regulations. 
Because, studies on the implementation of remission for Napimil in Lemasmil have not been carried out optimally, namely research conducted by Mahmud in 2020 related to the Development of Military Prisoners in Military Penitentiary; research conducted by Ali Ridlo in 2020 related to the Problematic Development of Military Prisoners; and research conducted by Suwarto related to the Development of Female Prisoners in Correctional Institutions. Broadly speaking, these studies conclude that the provision of remission and training for napimil both in Lemasmil and in general prisons is still not optimal.

Regarding the problems described above, it can be concluded that in the fulfilment of remission rights for prisoners, there is a legal vacuum. So that the problem can be formulated as follows:

a. What are the provisions regarding the ideal period of sentence reduction (Remission) for

Napimil?

b. What is the Legality of Granting Remissions to Napimil as Equal Rights Before the Law?

In accordance with the problems formulated above, the objectives to be achieved in this research are:

a. To study and analyse the ideal remission for Napimil.

b. To study and analyses the Legality of the Provision of Remissions to Napimil as Equal Rights Before the Law.

The method used is a normative juridical approach, with the main approach being normative juridical. For this reason, the approach method used is a normative analytical juridical approach, namely by examining the various applicable legal principles (positive law) relating to remissions for Napimil.

\section{Research Methods}

This research applied the normative juridical research method based on rules and literature and a study of the Constitutional Court Decision in the 2020 General Election (Pilkada). The normative juridical research method is based on the main law by examining theories, concepts, legal principles, and laws. Therefore, this is a qualitative study using the deductive reasoning method or a way of reasoning by drawing a conclusion based on general premises that have been proven

\section{Results and Discussion}

Lemasmil is the place to carry out training for Napimil. Every crime committed by the member of the Indonesian Armed Forces (TNI) is resolved at the Military Court and the execution of the sentence is carried out at Lemasmil. This provision is regulated in Article 10 of Law Number 39/1947 of the Military Criminal Code (KUHPM), which reads:

"Temporary imprisonment or imprisonment includes the punishment of substitute confinement imposed on the military, as long as he is not discharged from military service, he is served in buildings controlled by the military".

The Correctional Law Number 12 of 1995 affirms that the correctional system is held in order to form the Convict to become fully human, aware of mistakes, improve themselves and not repeat criminal acts so that they can be accepted back by the community, can play an active role in development and can live naturally as a good and responsible citizen. Corrections must 
show commitment in efforts to change the condition of the convict through a process of guidance and humane treatment of prisoners through protection of the rights of prisoners.

Every Prisoner and Child Prisoner who is serving a temporary prison sentence and imprisonment can be given remission if the person concerned has good behavior while serving the sentence, remission is given by the Minister of Law and Human Rights of the Republic of Indonesia, this is in accordance with the Presidential Decree of the Republic of Indonesia (Keppres RI) Number 174 Years 1999 on Remission.

Indonesia is a state based on law (rechstaat), so that in carrying out its main duties, the TNI is obliged to reflect the characteristics of a rule of law. According to Sri Soemantri there are four important elements of a rule of law, namely:

a. The government in carrying out its duties and obligations must be based on laws or statutory regulations.

b. There is a guarantee of human rights (to its citizens).

c. There is a division of power within the state.

d. The existence of supervision from judicial bodies (rechterlijke controle).

Meanwhile, Albert Van Dicey stated that there are 3 (three) main elements of the rule of law, namely:

a. Supremacy of law means that the one who has the highest power in the state is the law (the rule of law).

b. Equality before law.

c. The constitution is not a source of human rights and if those human rights are put in the constitution as an affirmation that human rights must be protected (constitution based of individual rights).

The characteristics and elements that are used as the support for the implementation of a rule of law must lead to one legal goal, namely the enforcement of justice, because basically laws are made and enforced to realize justice. Justice will be carried out if all components of the nation including the TNI are able to enforce law. Law enforcement within the TNI is carried out in order to guarantee discipline and readiness of soldiers in facing all forms of threats to state security and safety.

Law enforcement is essential and substantial in the concept of a rule of law like Indonesia. According to Edi Setiadi and Kristian, law enforcement is one part of legal development that leads to efforts to implement and apply or concretise law in real life to restore or restore balance in the order of life in society, nation and state. Law enforcement is a process to bring legal desires into reality, thus the law enforcement process will culminate in the implementation of legal regulations by law enforcement officials themselves. Law enforcers in the criminal justice system in Indonesia include police, prosecutors, judges, lawyers and prisons. Meanwhile, law enforcers within the TNI include judges, military prosecutors, military police, legal advisors, and military penitentiary institution.

\section{Conclusion}

Guidance for Napimil aims at integrated social reintegration so that the Napimils will become soldiers who have the identity of the TNI who are guided by the Soldiers 'Code of Ethics and / or Officers' Code of Ethics, realizing mistakes, correcting themselves, and not repeating criminal acts so that they can be accepted back into their units. in accordance with the provisions of laws and regulations. 
Thus, the provisions of remission to Napimil at Lemasmil is an effort for social reintegration of Napimil, so it needs to be regulated with clear regulations, related to the authority of the TNI Commander in granting approval for Remission requests. The provision of authority to the TNI Commander can only be done if the Correctional Law for Military has been issued. Given the importance of structuring the military correctional system, including the provision of remissions for Napimil, it is necessary to support the various competent parties to encourage the Military Correctional Bill to become a priority so that it can be immediately passed along with its derivative regulations.

\section{References}

[1] Bambang Waluyo, Penegakan Hukum di Indonesia (Law enforcement in Indonesia), Sinar Grafika, Jakarta, 2016

[2] Edi Setiadi dan Kristian, Sistem Peradilan Pidana Terpadu dan Sistem Penegakan Hukum di Indonesia (Integrated Criminal Justice System and Law Enforcement System in Indonesia), Prenadamedia Group, 2017

[3] Rosjidi Ranggawidjaja, Pengantar Ilmu Perundang-Undangan Indonesia (Introduction to Indonesian Legislation), Mandar Maju, Bandung, 1998

[4] R. Subekti,"Beberapa Pemikiran Mengenai Sistem Hukum Nasional Yang Akan Datang” (Some Thoughts Regarding the Future National Legal System). Paper in the Fourth National Law Seminar, 1979 Book II: Binacipta. Bandung 1993

[5] Salim HS dan Erlies Suptiana Nurbani, Penerapan Teori Hukum pada Penelitian Tesis dan Disertasi (Application of Legal Theory in Thesis and Dissertation Research), Rajawali Pers, Jakarta 2016

[6] Sri Soemantri, Bunga Rampai Hukum Tata Negara Indonesia (Interest of Indonesian Constitutional Law Compilation), PT.Alumni, Bandung ,1992

[7] Sunaryati Hartono, Politik Hukum Menuju Satu Sistem Hukum Nasional (Legal Politics Towards One National Legal System), Alumni, Bandung, 1991

[8] Van Dicey dalam Moh Kusnardir dan Harmaily Ibrahim, Pengantar Hukum Tata Negara Indonesia (Pengantar Hukum Tata Negara Indonesia), Indonesia Press, Jakarta, 1983

[9] Mahfud, Pembinaan Narapidana di Lembaga Pemasyarakatan Militer (Ditinjau Dari Perspektif Prinsip-Prinsip Yang Termuat Dalam Standart Minimum Rules For The Treatment of Prisoners Yang Diperluas Menjadi UN Nelson Mandela Rules), Development of Prisoners in Military Correctional Institutions (Viewed from the Perspective of the Principles Contained in the Standard Minimum Rules For The Treatment of Prisoners which were extended to become UN Nelson Mandela Rules), Doctoral Program Dissertation Ilmu Hukum, Universitas Jayabaya, Jakarta, 2020.

[10] Ali Ridlo, Problematika Pembinaan Narapidana Militer (The Problematic Development of Military Prisoners), Tulisan Edisi 59, Majalah Advokasi Babinkum TNI, Jakarta, 2020

[11] Suwarto, Pengembangan Ide Individualisasi Pidana Dalam Pembinaan Narapidana Wanita (Development of the Idea of Criminal Individualization in Guiding Female Prisoners), Dissertation of Doctor of Law Science Program, Universitas Sumatera Utara, Medan, 2017

[12] 1945 Indonesian Constitution.

[13] MPR's Decree Number VII/MPR/2000 concerning the Role of the TNI and Polri

[14] Military Court Law Number 31 of 1997

[15] Indonesian Armed Forces Law Numer 34 of 2004

[16] Indonesian Prosecutor Law Number 16 of 2004

[17] Law Number 12 of 2011 concerning Formation of Legislative Regulations as amended by Law Number 15 of 2019 concerning Amendments to Law Number 12 of 2011 concerning the Formation of Legislative Regulations

[18] Law Number 30 of 2014 concerning Government Administration

[19] Henry Campbell Black, Black's Law Dictionary, Fifth Editions, (USA: ST. Paul Minn. West Publishing Co., 1997

[20] Pusat Bahasa, Kamus Besar Bahasa Indonesia Edisi Ketiga, Balai Pustaka Jakarta, 2005 
[21] http://tesisdisertasi.blogspot.com/2020/10/narapidana, diakses pada tanggal 7 Juli 2020. 